\title{
Computer-aided method for merger and balance of working procedure in Apparel assembly line
}

\author{
Hongqin Dai \\ National Engineering Laboratory for Modern Silk, \\ College of Textile and Clothing Engineering \\ Soochow University \\ Suzhou, China \\ e-mail: dhq1970@163.com
}

\author{
Lili Chen \\ National Engineering Laboratory for Modern Silk, \\ College of Textile and Clothing Engineering \\ Soochow University \\ Suzhou, China \\ e-mail: 352715000@qq.com
}

\author{
Guolian Liu \\ National Engineering Laboratory for Modern Silk, College of Textile and Clothing Engineering \\ Soochow University \\ Suzhou, China \\ e-mail: liuguolian@suda.edu.cn
}

\begin{abstract}
Apparel assembly line involves a set of workstations. It is difficult to attain a perfectly balanced apparel assembly line because of the different production rate of each workstation. In order to obtain a relatively balance of assembly line, it is necessary to make merger of basis working procedures. In the paper, a new method for merger and balance of working procedure in Apparel assembly line is presented. The method can finish merger working procedures on the basis of basic demand of apparel assembly line. Based on the method, a system is developed and case study shows that the system can well finish the work of merger working procedure.
\end{abstract}

Keywords-apparel assembly line; merger and balance of working procedur; computer-aied method

\section{INTRODUCTION}

Assembly lines have been widely used in most companies. It is very important for industry because it provides increasing production speed, a considerable planning, and it helps industries to improve their economic problems [1,2]. At present, assembly line management aims to promote line balancing. There are many researches about line balancing such as Whitaker's mathematical model [3] , interactive modeling techniques [4] and a knowledge-based approach [5].

Apparel assembly line involves a set of workstations in which a specific task in a predefined sequence is processed. Industrial experience shows that it is difficult to attain a perfectly balanced line because of the different production rate of each workstation. In order to obtain relatively balancing line, it is necessary to merger and balance working procedure on the garment working procedure flow chat. Currently there are mainly two methods to resolve problem on merger and balancing working procedure in garment assembly line. The first method is genetic algorithm $[6,7,8]$. It adopts genetic algorithm to solve clothing balancing problems. due to the shortcoming of genetic algorithm, the application of the method is limited. The second method is that designer creates the vector graph and marks off priority area based on predigesting working procedure analytic diagram, and groups organization is finished by priority connection, priority area and assembled range [9]. In the method, a worker may be assigned to operate different sewing machine.

At present, the sewing line supervisors manage garment assembly line by experiences and manual method. the shortcomings of the traditional method are that the efficiency is low and there are bottlenecks in assembly line. With the development of computer technology, the computer technology already has been applied in some clothing field such as clothing design. However, the study and application of computer-aided Apparel assembly line manage are less. In the paper, a computer-aided method for merger and balance working procedure in apparel assembly line is proposed.

\section{Method For Merger AND BALANCE WorkING PROCEDURE}

To improve productive efficiency, apparel assembly line should meet three basic demands:

(1) Reasonably distribute jobs to each workstation according to working procedure flow, avoid the situation of backward flow in assembly line.

(2) Make sure processing time of each workstation approach tempo as much as possible.

(3) Make spare time of each workstation less, load of workstation uniform and ensure the time loss ratio of total assembly line lowest.

Based on above three basic demands, a new method to merger and balance working procedure was presented. The main procedures are as followings. 


\section{A. Analyse And Compute Dependent Procedures And Influence Of Working Procedure}

In the paper, the dependent procedures and influence of working procedure are defined in order to following process. These working procedures which should be finished before certain working procedure are called dependent procedure of the working procedure. When there is no dependent procedure for one procedure, it indicates that the procedure can be processed now. Influence of working procedure indicates degree how many procedures are dependent on current procedure. According to dependent procedure of each procedure, the influence of each procedure can be obtained.

\section{B. Compute Tempo Of Apparel Assembly Line}

The tempo of apparel assembly line is decided by total time and number of worker needed for finishing a piece of garment. The tempo of apparel assembly line is obtained by following equation:

$$
\tau=\frac{T}{N}
$$

According to define of tempo of apparel assembly line, we can obtain the upper bound and lower bound of tempo.

$$
\begin{gathered}
\tau_{u}=\frac{\tau}{E} \\
\tau_{l}=2 \tau-\tau_{u}
\end{gathered}
$$

Where $\tau$ is tempo, $T$ is time, $N$ is number of worker, $\tau_{u}$ is upper bound of tempo, $\tau_{l}$ is lower bound of tempo, $E$ is planning efficiency.

\section{Set Rules Of Merger And Balance Working Procedure}

The main rules are:

(1) The situation of backward flow in assembly line is prohibited.

(2) Procedures in the same branch are assigned to one merger procedure as much as possible.

(3) The total time of merger procedure is close to productive tempo or integral multiple of procedure tempo.

(4) Only these procedures involving same machine can be combined.

(5) The merger procedure with the biggest total influence of merger procedure in all merger procedures which accord with tempo demand has priority.

\section{Operate Merger And Balance Of Apparel Working Procedure}

The program of merger and balance working procedure is as following:

Step1: Compute dependent procedures of each working procedure

Step2: If all procedures have been finished, then the program is end or else program go to Step3

Step3: Find out all procedures that do not have dependent procedures and form a ensemble which is sign $\mathrm{P}$.

Step4: Choose one procedure from $\mathrm{P}$.
Step5: Set the procedure as current procedure, search any possible merger procedures in the same branch and $\mathrm{P}$ according to above rules. Meanwhile judge whether merger procedure is accord with tempo demands and record the information.

Step6: When there are merger procedures according with tempo demands, program go to Step7, or else go to Step8.

Step7: Search merger procedure with the biggest influence, output it as final merger procedure, and go to Step9.

Step8: Search merger procedure which is the closest to tempo demands, output it as final merger procedure, and go to Step9.

Step9: Update dependent procedures of each procedure and go to Step2.

\section{SYSTEM REALIZATION}

Apparel procedure flow chat shows all procedures and their order. To be convenient for analyzing and handing procedures in computer, it is necessary to present the chat by certain data construct. In the paper, linear list is used to store apparel procedure flow. The structure of node includes working procedure ID, type, time, branch, father branch and insert position. The structure of node in list is shown in Fig. 1.

\begin{tabular}{|l|l|l|l|l|l|}
\hline ID & Type & Time & Branch & Father branch & Insert place \\
\hline
\end{tabular}

Figure 1. the structure of node in list

The system is finished by using Microsoft Visual Studio 2008. Fig. 2 is the main windows of system.

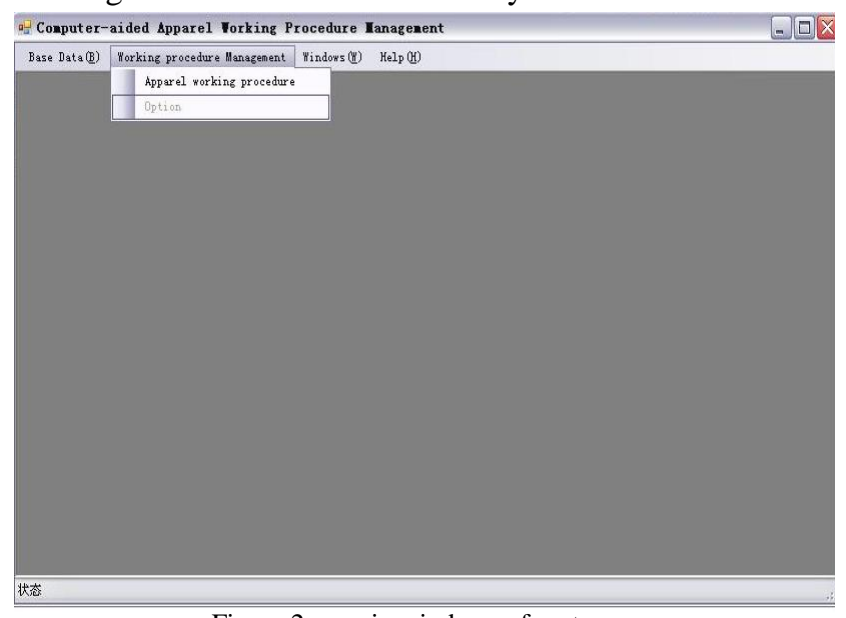

Figure 2. main windows of system 


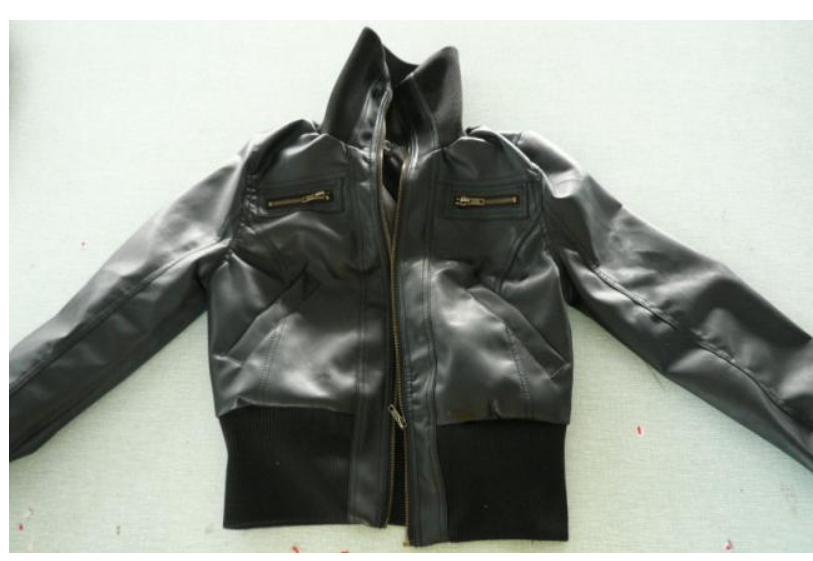

Figure 3. Woman's Jacket

\section{CASE STUdY}

This case is women's jacket shown in Fig. 3. In this case, tempo is $45 \mathrm{~s}$ and planning efficiency is $85 \%$. According to Eq. (2) and Eq. (3), we can obtain $\tau_{u}=53 \mathrm{~s}$ and $\tau_{l}=37 \mathrm{~s}$. There are 50 basis working procedures in the garment. Table 1 shows these working procedures. The result of merger working procedure is shown in Table 1 . Table 1 shows that most of merger working procedures accord with tempo demands.

TABLE I. BASIS WORKING PROCEDURES

\begin{tabular}{|c|c|c|c|c|c|}
\hline $\begin{array}{l}\text { working } \\
\text { procedure } \\
\text { ID }\end{array}$ & Time(S) & Type & Branch & $\begin{array}{l}\text { Father } \\
\text { branch }\end{array}$ & $\begin{array}{l}\text { Insert } \\
\text { place }\end{array}$ \\
\hline 1 & 17 & handmake & 11 & 11 & 0 \\
\hline 2 & 28 & $\begin{array}{l}\text { sewing } \\
\text { machine }\end{array}$ & 11 & 11 & 0 \\
\hline 3 & 23 & $\begin{array}{c}\text { double } \\
\text { needle } \\
\text { machine }\end{array}$ & 11 & 11 & 0 \\
\hline 4 & 15 & handmake & 11 & 11 & 0 \\
\hline 5 & 36 & $\begin{array}{l}\text { sewing } \\
\text { machine }\end{array}$ & 1101 & 11 & 7 \\
\hline 6 & 20 & $\begin{array}{l}\text { sewing } \\
\text { machine }\end{array}$ & 1101 & 11 & 7 \\
\hline 7 & 51 & $\begin{array}{l}\text { sewing } \\
\text { machine }\end{array}$ & 11 & 11 & 0 \\
\hline 8 & 47 & $\begin{array}{l}\text { sewing } \\
\text { machine }\end{array}$ & 11 & 11 & 0 \\
\hline 9 & 15 & $\begin{array}{l}\text { sewing } \\
\text { machine }\end{array}$ & 11 & 11 & 0 \\
\hline 10 & 14 & $\begin{array}{l}\text { sewing } \\
\text { machine }\end{array}$ & 1102 & 11 & 14 \\
\hline 11 & 26 & $\begin{array}{l}\text { sewing } \\
\text { machine }\end{array}$ & 1102 & 11 & 14 \\
\hline 12 & 65 & $\begin{array}{l}\text { sewing } \\
\text { machine }\end{array}$ & 1102 & 11 & 14 \\
\hline 13 & 15 & handmake & 1102 & 11 & 14 \\
\hline 14 & 97 & $\begin{array}{l}\text { sewing } \\
\text { machine }\end{array}$ & 11 & 11 & 0 \\
\hline 15 & 39 & $\begin{array}{l}\text { double } \\
\text { needle }\end{array}$ & 1103 & 11 & 18 \\
\hline
\end{tabular}

\begin{tabular}{|c|c|c|c|c|c|}
\hline & & machine & & & \\
\hline 16 & 13 & $\begin{array}{l}\text { sewing } \\
\text { machine }\end{array}$ & 1103 & 11 & 18 \\
\hline 17 & 6 & $\begin{array}{c}\text { double } \\
\text { needle } \\
\text { machine }\end{array}$ & 1103 & 11 & 18 \\
\hline 18 & 24 & $\begin{array}{l}\text { sewing } \\
\text { machine }\end{array}$ & 11 & 11 & 0 \\
\hline 19 & 37 & $\begin{array}{l}\text { sewing } \\
\text { machine }\end{array}$ & 1104 & 11 & 21 \\
\hline 20 & 38 & $\begin{array}{l}\text { double } \\
\text { needle } \\
\text { machine }\end{array}$ & 1104 & 11 & 21 \\
\hline 21 & 44 & $\begin{array}{l}\text { sewing } \\
\text { machine }\end{array}$ & 11 & 11 & 0 \\
\hline 22 & 38 & $\begin{array}{c}\text { double } \\
\text { needle } \\
\text { machine }\end{array}$ & 11 & 11 & 0 \\
\hline 23 & 37 & $\begin{array}{l}\text { sewing } \\
\text { machine }\end{array}$ & 11 & 11 & 0 \\
\hline 24 & 18 & handmake & 1105 & 11 & 26 \\
\hline 25 & 7 & handmake & 1105 & 11 & 26 \\
\hline 26 & 45 & $\begin{array}{l}\text { sewing } \\
\text { machine }\end{array}$ & 11 & 11 & 0 \\
\hline 27 & 238 & $\begin{array}{c}\text { offline } \\
\text { manufacture }\end{array}$ & 1106 & 11 & 34 \\
\hline 34 & 56 & $\begin{array}{l}\text { sewing } \\
\text { machine }\end{array}$ & 11 & 11 & 0 \\
\hline 35 & 12 & handmake & 1107 & 11 & 36 \\
\hline 36 & 59 & $\begin{array}{c}\text { double } \\
\text { needle } \\
\text { machine }\end{array}$ & 11 & 11 & 0 \\
\hline 37 & 12 & handmake & 1108 & 11 & 40 \\
\hline 38 & 18 & handmake & 1108 & 11 & 40 \\
\hline 39 & 24 & $\begin{array}{l}\text { sewing } \\
\text { machine }\end{array}$ & 1108 & 11 & 40 \\
\hline 40 & 51 & $\begin{array}{l}\text { sewing } \\
\text { machine }\end{array}$ & 11 & 11 & 0 \\
\hline 41 & 44 & $\begin{array}{l}\text { sewing } \\
\text { machine }\end{array}$ & 11 & 11 & 0 \\
\hline 42 & 19 & handmake & 1109 & 11 & 43 \\
\hline 43 & 48 & $\begin{array}{l}\text { sewing } \\
\text { machine }\end{array}$ & 11 & 11 & 0 \\
\hline 44 & 13 & $\begin{array}{l}\text { sewing } \\
\text { machine }\end{array}$ & 1110 & 11 & 46 \\
\hline 45 & 19 & handmake & 1110 & 11 & 46 \\
\hline 46 & 32 & $\begin{array}{l}\text { sewing } \\
\text { machine }\end{array}$ & 11 & 11 & 0 \\
\hline 47 & 81 & $\begin{array}{l}\text { sewing } \\
\text { machine }\end{array}$ & 11 & 11 & 0 \\
\hline 48 & 35 & handmake & 11 & 11 & 0 \\
\hline 49 & 44 & $\begin{array}{c}\text { double } \\
\text { needle } \\
\text { machine }\end{array}$ & 11 & 11 & 0 \\
\hline 50 & 15 & $\begin{array}{l}\text { sewing } \\
\text { machine }\end{array}$ & 11 & 11 & 0 \\
\hline
\end{tabular}


TABLE II.

Result Of MERger Working Procedure

\begin{tabular}{|c|c|c|c|}
\hline $\begin{array}{c}\text { Merger } \\
\text { working } \\
\text { procedure } \\
\text { ID }\end{array}$ & Type & $\begin{array}{l}\text { Working } \\
\text { procedure }\end{array}$ & $\begin{array}{c}\text { Time } \\
\text { (S) }\end{array}$ \\
\hline 1 & handmake & $35,24,1$ & 47 \\
\hline 2 & sewing machine & $44,5,2$ & 77 \\
\hline 3 & sewing machine & 10,11 & 40 \\
\hline 4 & sewing machine & 12,6 & 85 \\
\hline 5 & handmake & $45,25,13$ & 42 \\
\hline 6 & double needle machine & 15,3 & 62 \\
\hline 7 & sewing machine & 19,16 & 50 \\
\hline 8 & double needle machine & 20,17 & 44 \\
\hline 9 & offline manufacture & 27 & 238 \\
\hline 10 & handmake & $42,37,4,38$ & 64 \\
\hline 11 & sewing machine & 7 & 51 \\
\hline 12 & sewing machine & 8 & 47 \\
\hline 13 & sewing machine & 9,14 & 112 \\
\hline 14 & sewing machine & 18,21 & 68 \\
\hline 15 & double needle machine & 22 & 38 \\
\hline 16 & sewing machine & 23 & 37 \\
\hline 17 & sewing machine & 26 & 45 \\
\hline 18 & sewing machine & 34 & 56 \\
\hline 19 & double needle machine & 36 & 59 \\
\hline 20 & sewing machine & 39,40 & 75 \\
\hline 21 & sewing machine & 41 & 44 \\
\hline 22 & sewing machine & 43 & 48 \\
\hline 23 & sewing machine & 46,47 & 113 \\
\hline 24 & handmake & 48 & 35 \\
\hline 25 & double needle machine & 49 & 44 \\
\hline 26 & sewing machine & 50 & 15 \\
\hline
\end{tabular}

\section{CONCLUSIONS}

In the paper, we proposed a computer-aided method for merger and balance of working procedure in apparel assembly line. The method can finish merger working procedures on the basis of basic demand of apparel assembly line. Based on the method, a system is developed and case study shows that the system can well finish the work of merger working procedure.

\section{ACKNOWLEDGMENT}

This work is financed by the Project Funded by the Priority Academic Program Development of Jiangsu Higher Education Institutions, China.

\section{REFERENCES}

[1] B.Render, J. Heizer, Productions \& Operations Management, Prentice Hall, New Jersey. 1996.

[2] Ma, X., Finding the best possible solution to simple assembly line balancing problems,Product Instn Mechanical Engineers Vol. 211 Part B, 53 - 61,1997

[3] D. Whitaker, A study of a production line in the garment industry, Cloth. Inst. J., vol. 21, pp. 113-120, 1973.

[4] R. D. Hurrion, Visual interactive modeling, Eur. J. Oper. Res., vol. 23, pp. 281-287, 1986.

[5] G. Fozzard, J. Spragg, and D. Tyler, Simulation of flowlines in clothing manufacture-Part I: Model construction, Int. J. Cloth. Sci. Technol.,vol. 8, pp. 17-27, 1996.

[6] DongyunWang, Huiqin Liu,Luoyan Hu,Delin Ling,A GeneticAlyorithm-Based Scheduling Techniques for Clothing Sewing, Journal of Textile Research. vol. 24, pp. 440-442, 2002.

[7] Zhaoxia Guo,Jianan Fang,An Application of Genetic Algorithm in Clothing Sewing Assembly Line Balancing Problem, Computer Sim ulation, vol. 20, pp. 98-99, 2003.

[8] Huiqin Liang,Shumin Fei, An Application of Self-Adaption Genetic Algorithm in Clothing Sewing Assembly Line Balancing Problem,Industrial Control Comuter, vol. 22, pp. 57-59, 2009.

[9] Yulin Li,Luoyan Hu, Dongyun Wang, Deling Ling,Computer Aids for Clothing Sewing Assembly Line Optimized Dispatching, Journal of Zhongyuan University of Technology, vol.13, pp. 35-36, 2002.

[10] Mesut OZGURLER, Ali Fuat GUNERI, Bahadir GULSUN, A Simulation Approach to Line Balancing in Discrete Mass Production Flow System and An Application, International Journal of Clothing Science and Technology, vol.10, pp.21-37, 1998. 